\title{
The Effect of Organic Matter on the Growth of various Water Plants in Culture Solution.
}

\author{
$\mathrm{BY}$ \\ W. B. BOTtomley, M.A., Pн. D, \\ Professor of Botany at King's College, London.
}

With Plate XVII.

THE importance of organic manures in agricultural operations is a well1 recognized fact, and a considerable amount of evidence has been accumulated by the author in support of the view that such organic manures are of direct importance in the nutrition of the plant, quite apart from their indirect effect in altering and improving the physical condition of the soil and in providing food for soil bacteria. It has already been shown that plants of Lemna minor will not grow and flourish normally in solutions containing mineral nutrients only, and that the addition to such nutrient solutions of small quantities of organic substances obtained from decomposing vegetable matter, ${ }^{1}$ from cultures of nitrogen-fixing organisms, and from nucleic acid and its derivatives ${ }^{2}$ which the author has found can be extracted from raw peat, ${ }^{3}$ enable the plants to multiply rapidly and retain their healthy appearance.

It has also been shown ${ }^{4}$ that the failure of a pure inorganic solution to support normal growth in these plants is not due to an unsuitable balance of nutrient materials, for similar results were obtained with more than one solution in common use among experimenters with water cultures; while trials carried out with water of the pond in which the plants were growing showed that in this medium they maintained their normal health and vigour, although their rate of multiplication was retarded as compared with that in the artificial nutrient solution, presumably owing to the lack of any large quantities of the essential inorganic materials in the pond water. The organic matter, which this water contained to the amount of nearly five hundred parts per million, enabled the plants to grow healthily throughout.

1 Bottomley, W. B. : Proc. Roy. Soc., B., vol. lxxxix, pp. 48I-507 (I9I 7).

2 Ibid., vol. xci, pp. 83-95 (I9I9).

3 Ibid., vol. xc, pp. 39-44 (I9I 7).

1 Ibid.: Annals of Botany, vol. xxxiv, No. $\operatorname{exxxv}(1920)$.

[Annals of Botany, Vol. XXXIV. No. CXXXV. July, 1920.] 
The question arose as to whether this necessity for organic matter is a peculiarity of water plants as distinct from land plants, and whether, among water plants, Lemna stands alone in such requirement. A preliminary experiment has already been reported with Lemna major, ${ }^{1}$ which indicated that the behaviour of this plant corresponds with that of Lemna minor in that it fails to grow normally in a mineral solution, while the addition of water-soluble organic matter from bacterized peat enables it to maintain its health and increase its rate of multiplication. This experiment, however, was essentially of a preliminary nature, and was carried out towards the end of the growing season when no rapid multiplication could be expected.

\section{EXPERIMENTS WITH LEMNA MAJOR.}

A more extensive trial with Lemna major was made about the middle of May, to determine whether this plant would still fail to grow well in mineral nutrients even during the good growing season, and also to discover whether organic substances other than bacterized peat could supply the deficiency in this case as in the case of Lemna minor.

Four series of five dishes each were arranged, each containing I 50 c.c. of Detmer's solution. The dishes of Series I, numbered from I to 5 , served as controls, while the following additions were made to the other dishes: Series II, numbered from 6 to IO, the crude nucleic acid derivatives from one gramme of raw peat in every 500 c.c. of solution; Series III, numbered from I I to I5, one gramme of autoclaved Azotobacter growth in every I,000 c.c.; and Series IV, numbered from 16 to 20 , the water extract of one gramme of bacterized peat in every 500 c.c. These various substances were obtained in precisely the same way as described in the previous publications.

Ten plants of Lemna major were counted out into each dish, and care was taken to select very young plants, instead of full-grown ones, in order that their size might be more uniform. Three hundred similar plants were taken at the same time and well washed for an estimation of their dry weight, which was found to be $24.2 \mathrm{mg}$. for 100 plants.

The dishes were surrounded up to the level of the liquids with paper which was black on the side towards the dish and white towards the outside, in order to exclude light from the bottom and sides. The whole set was covered with a large sheet of glass supported a little above the top of the dishes, in order to prevent the access of dust as much as possible. The solutions were changed twice weekly, and the plants counted once weekly, care being taken to exclude green algae as much as possible. The figures obtained in the first three weeks of the experiment are shown in the table below :

1 Bottomley, W. B.: Annals of Botany, vol. xxxiv, No. $\operatorname{cxxxv}$ (I920). 


\section{TABLE I.}

Series. Dish No. Ist week. and week. 3rd week.

I. Detmer's solution

$\begin{array}{cccc}\text { I } & 18 & 25 & 30 \\ 2 & 18 & 22 & 28 \\ 3 & 18 & 23 & 26 \\ 4 & 18 & 23 & 28 \\ 5 & 18 & 24 & 30 \\ \text { Mean } & \text { 18 } & \overline{23 \cdot 4} & \mathbf{2 8 . 4}\end{array}$

II. Detmer's solution + crude nucleic acid derivatives

\begin{tabular}{|c|c|c|c|}
\hline 6 & 26 & 57 & I79 \\
\hline 7 & 24 & $5 I$ & 163 \\
\hline $\begin{array}{l}8 \\
9\end{array}$ & $\begin{array}{l}20 \\
23\end{array}$ & & $\begin{array}{l}189 \\
156\end{array}$ \\
\hline 10 & 24 & 57 & 184 \\
\hline Mean & $24 \cdot 6$ & $54 \cdot 4$ & 174.2 \\
\hline
\end{tabular}

III. Detmer's solution + autoclaved Azotobacter

$\begin{array}{cccc}\text { I1 } & 20 & 33 & 6 \text { I } \\ \text { I } & 19 & 27 & 5 \text { I } \\ 13 & 19 & 28 & 54 \\ \text { I4 } & 20 & 32 & 59 \\ 15 & 20 & 29 & 49 \\ \text { Mean } & \text { 19.6 } & \underline{29.8} & 54.8\end{array}$

IV. Detmer's solution +

$\begin{array}{cccc}16 & 24 & 65 & 250 \\ 17 & 23 & 71 & 272 \\ 18 & 22 & 67 & 258 \\ 19 & 22 & 63 & 246 \\ 20 & 25 & 71 & 250 \\ \text { Mean } & \underline{23 \cdot 2} & \overline{67 \cdot 4} & \mathbf{2 5 5 \cdot 2}\end{array}$

At the end of three weeks the numbers and also the appearance of the individual plants were so striking as to render the continuation of the whole series unnecessary, so on account of pressure of other work the experiment as a whole was brought to a close, although the dishes of Series I and IV were halved, one half of each dish being used for an estimation of the dry weight of the plants, and the other half of these two series being continued for a further period of three weeks. At the end of this time the average number of plants in Series I, resulting from the original Io, was 72 , and that in Series IV $4,704$.

At the time when the main part of the experiment ceased, three weeks after its commencement, the plants in Series I were extremely small and yellow and unhealthy in appearance. The plants, though not full-grown at the beginning of the experiment, had never increased in size, but had budded slowly, the new plants formed being successively smaller than the originals -so much so that it was quite easy at the end to pick out the original ten which were placed in the dishes, on account of their larger size. The plants in Series II, III, and IV at the end of the three weeks were all large, 
green, and healthy in appearance. A comparison of the dry weights of the plants at this period gave the following figures:

Io० plants at the beginning in all series weighed $24.8 \mathrm{mg}$. I00 plants after three weeks in Series I " 20.4 "

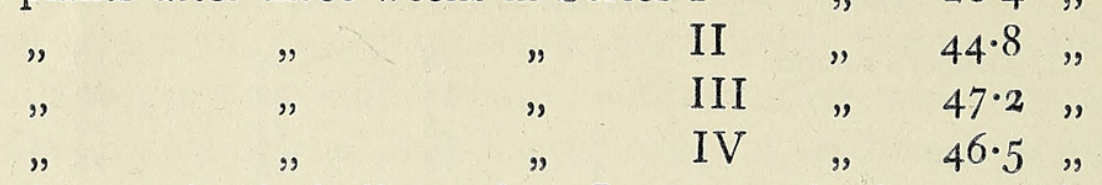

These figures clearly indicate that Lemna major is not able to maintain a good healthy growth in solutions containing only mineral nutrients, and that the addition of the various organic substances supplied corrected the deficiency and enabled the plants to grow more luxuriantly and preserve a thoroughly healthy appearance. The varying effect of the different substances added is chiefly shown in their influence on the rate of multiplication, for the weights of the plants in all the series containing organic matter were approximately equal, and all appeared equally healthy.

It was pointed out that the plants used in these experiments were immature at the beginning, so a further trial was made in July, when a fresh supply of these plants came to hand, to determine whether fully-grown plants could remain healthy in inorganic nutrients only.

Two series, each consisting of five dishes, were arranged, those of Series I, numbered from I to 5, each containing 200 c.c. of Detmer's solution, and those of Series II, numbered from 6 to Io, containing a similar quantity of the same solution, which also contained the water extract of I grm. of bacterized peat in every 500 c.c. Ten full-grown plants of Lemna major were placed in each dish, and three hundred similar plants used for an estimation of their dry weight. The dishes were treated precisely as before, for four weeks, and the following figures were obtained :

\section{TABLE II.}

Series.

I. Detmer's solution

Detmer's solution + bacterized peat
Dish No. Ist week. 2nd wreek. 3rd week. 4th week.

$\begin{array}{ccccc}\text { I } & \text { I6 } & 20 & 21 & 30 \\ 2 & 13 & 18 & 20 & 29 \\ 3 & 13 & 17 & 20 & 26 \\ 4 & 12 & 16 & 19 & 25 \\ 5 & 17 & 18 & 2 I & 28 \\ \text { Mean } & 13 \cdot 8 & \overline{17 \cdot 8} & \overline{20 \cdot 2} & \overline{27 \cdot 6} \\ 6 & 24 & 48 & 99 & 166 \\ 7 & 28 & 53 & 113 & 197 \\ 8 & 26 & 50 & 104 & 173 \\ 9 & 25 & 49 & 92 & 168 \\ 10 & 24 & 51 & 103 & 192 \\ \text { Mean } & 25 \cdot 4 & 50 \cdot 2 & 102 \cdot 2 & 177 \cdot 2\end{array}$

The plants in dishes $2,5,6$, and 8 , which were nearest to the mean, were pressed and mounted as a permanent record, and photographs of these 
pressed plants are shown in Pl. XVII, Figs. I and 2. The plants in the remaining dishes were used for determinations of the dry weight of the plants, with the following results :

100 plants at the beginning of the experiment in both series

oo plants at the fourth weighed $3^{8 \cdot 4} \mathrm{mg}$.

Ioo plants at the fourth week in Series I " 22.0 ,

Even though these "plants were fully II " $5 \mathrm{I}^{\circ} 9$ ",

Even though these plants were fully grown to begin with, their offspring were clearly unable to attain their normal size in the mineral nutrients, while those supplied with organic matter appreciably increased upon the weight of the original plants. The yellowish colour of the control plants was in such marked contrast to the rich green of those in the organic substance that it was feared that the nutrient solution might be lacking in sufficient quantity of iron. An extra quantity of iron was therefore added to the control series, but it had absolutely no effect on either colour or size of the plants.

It is clear from these experiments that certain organic substances are quite as necessary for Lemna major as for Lemna minor, and that without such materials the plants rapidly become unhealthy, their individual weight being diminished and their rate of multiplication retarded.

\section{EXPERIMENTS WITH SALVINIA NATANS.}

Somewhat late in the season, towards the end of August, some experiments were commenced with Salvinia natans. A set of ten dishes was prepared, divided into two series of five dishes each. Those of Series I, numbered from I to 5 , each contained 250 c.c. of Detmer's solution, and those of Series II, numbered from 6 to IO, contained a similar quantity of this solution with the addition of the extract from one gramme of bacterized peat per I,000 c.c. Into each of the dishes were put small sprigs of Salvinia natans. It was a little more difficult than in the case of Lemna to select absolutely uniform samples of this plant, but the portions in the ten dishes were chosen as equally as possible, each dish receiving two sprigs each consisting of three leaves and a bud, and two sprigs of two leaves and a bud each. Each dish therefore contained ten full-grown leaves and four buds. Four similar sets were chosen at the same time and their dry weights estimated. The figures obtained were $10.4,10.0,10.0$, and $10.2 \mathrm{mg}$. respectively, giving an average of $10.15 \mathrm{mg}$. as the original dry weight of each set. The under surface and the roots of these plants when received were closely covered with a mass of blue-green algae, which was carefully removed by washing before the experiment commenced. The dishes were surrounded with black paper as explained above, and protected from dust. Twice weekly the liquids were renewed, and a weekly record was made of the number of fully-opened leaves in each dish. At the end of seven 
weeks the plants in Series II had completely filled their dishes, so they were all halved as exactly as possible and the dry weight of one half of each dish estimated. This was repeated at the end of the eighth and eleventh weeks respectively. The experiment lasted for twelve weeks altogether, and the following figures were obtained :

\section{TABLE III.}

\begin{tabular}{|c|c|c|c|c|c|c|}
\hline \multirow{2}{*}{$\begin{array}{l}\text { No. of } \\
\text { Leaves } \\
\text { at end } \\
\text { of }\end{array}$} & \multicolumn{6}{|c|}{$\begin{array}{l}\text { Series I. } \\
\text { etmer's Solution. } \\
\text { Dish Number. }\end{array}$} \\
\hline & I & 2 & 3 & 4 & 5 & Mean. \\
\hline Ist week & 15 & I 3 & I 2 & I4 & I 4 & I 3.6 \\
\hline 2nd & 2 I & 20 & I7 & 20 & I 8 & 19.2 \\
\hline $3^{\text {rd }}$ & 29 & 27 & 24 & 29 & 28 & $27 \cdot 4$ \\
\hline $4^{\text {th }}$ & $4 \mathrm{I}$ & 40 & $4^{i}$ & 40 & $4^{2}$ & 40.8 \\
\hline $5^{\text {th }}$ & $4^{8}$ & 49 & 45 & 52 & $4^{8}$ & $4^{8 \cdot 4}$ \\
\hline 6 th & 62 & 69 & $6 I$ & 69 & 62 & 64.6 \\
\hline $7^{\text {th }}$ & 84 & 98 & 84 & IIO & 92 & 93.6 \\
\hline 8th & I 20 & I 44 & 128 & I 56 & 148 & I 39.2 \\
\hline $9^{\text {th }}$ & I 52 & 180 & I $5^{2}$ & I 80 & 164 & 165.6 \\
\hline oth & 160 & I 80 & I 52 & 192 & 168 & 170.4 \\
\hline I I th & 160 & 192 & I 68 & 216 & 176 & 182.4 \\
\hline 2 th & 168 & 224 & I 76 & 240 & 176 & I96.8 \\
\hline
\end{tabular}

Series II.
Detmer's Solution + Bacterized Peat.
Dish Number.

\begin{tabular}{|c|c|c|c|c|c|}
\hline 6 & 7 & 8 & 9 & 10 & Mean. \\
\hline I 2 & I7 & 16 & 15 & 19 & ${ }_{1} 5.8$ \\
\hline 2 I & 25 & 24 & $2 \mathrm{I}$ & 27 & 23.6 \\
\hline $3^{2}$ & 34 & $3^{\mathrm{I}}$ & 3.3 & 36 & $33 \cdot 2$ \\
\hline $5 \mathrm{I}$ & 54 & 53 & $5^{6}$ & 55 & 53.8 \\
\hline 64 & 73 & 62 & 73 & 73 & 69.0 \\
\hline $9^{2}$ & 107 & 105 & 104 & I I 4 & 104.4 \\
\hline$I_{4}^{2}$ & 1 36 & I 44 & 148 & ${ }^{1} 5^{2}$ & 144.4 \\
\hline 212 & 236 & 232 & $25^{6}$ & 252 & $237 \cdot 6$ \\
\hline 272 & 336 & 304 & 344 & $34^{8}$ & 320.8 \\
\hline 284 & 376 & 344 & $3^{88}$ & $3 T^{2}$ & $35^{2 \cdot 8}$ \\
\hline $3^{20}$ & 400 & $3^{84}$ & $45^{6}$ & 408 & 393.6 \\
\hline $39^{2}$ & $44^{\circ}$ & 408 & 496 & $4^{6} 4$ & 440.0 \\
\hline
\end{tabular}

It will be observed that the rate of growth of the plants diminished in both series towards the end of the experiment, owing to the lowering of the temperature during October and November. The figures obtained for the dry weights of the whole of the plants in the two series, calculated from the weights of the halves on the three occasions on which the plants were divided, are as follows :

\section{TABLE IV.}

\begin{tabular}{|c|c|c|c|c|c|c|c|c|c|c|c|c|}
\hline $\begin{array}{l}\text { Weight of } \\
\text { Plants in }\end{array}$ & & & $\begin{array}{c}S e \\
\text { Dish }\end{array}$ & $\begin{array}{l}\text { ries } I \text {. } \\
\text { Numbe }\end{array}$ & & & & & $\begin{array}{l}\text { Ser } \\
\text { Dish }\end{array}$ & $\begin{array}{l}\text { es II. } \\
\text { Numbe }\end{array}$ & & \\
\hline$m g$. at endo & I & 2 & 3 & 4 & 5 & Mean. & 6 & 7 & 8 & 9 & 10 & Mean. \\
\hline th week & $80 \cdot 0$ & $83 \cdot 2$ & 88.8 & 92.6 & $84 \cdot 4$ & 86.0 & $69 \cdot 2$ & I $48 \cdot 4$ & I 56.8 & I $54 \cdot 4$ & I $58 \cdot 0$ & I $57 \cdot 4$ \\
\hline 8 th & $104 \cdot 0$ & 105.6 & $95 \cdot 6$ & $13^{2.0}$ & I $17 \cdot 2$ & I 10.9 & 276.0 & 213.6 & 232.8 & 249.6 & $243 \cdot 2$ & $243 \cdot 0$ \\
\hline I I th & I 40.8 & $147 \cdot 2$ & I 50.4 & $16 I \cdot 6$ & $142 \cdot 4$ & $14^{8 \cdot 5}$ & $4^{6} 5 \cdot 6$ & $55^{6.8}$ & $5^{26} \cdot 4$ & $574 \cdot 4$ & $549^{\circ} 2$ & $53^{2 \cdot} \cdot 5$ \\
\hline
\end{tabular}

The number of leaves in each dish at the beginning of the experiment, neglecting buds, was ten, and the average weight of the sets was $10.15 \mathrm{mg}$. This corresponds to an average weight for 100 leaves of $10 \mathrm{I} \cdot 5 \mathrm{mg}$. at the beginning of the experiment. Comparing this with the calculated weight of 100 leaves at the end of the seventh, eighth, and eleventh weeks respectively, the following results are obtained:

\section{TABLE V.}

Series $I$.

$\begin{array}{cccc}\text { Average No. } & \begin{array}{c}\text { Average } \\ \text { Weight. } \\ \text { of Leaves. }\end{array} & \begin{array}{c}\text { Calculated } \\ \text { Weight of } \\ \text { 100 Leaves. } \\ \text { mg. }\end{array} \\ \text { At beginning } & 10 & 10.15 & 101.5 \\ \text { 7th week } & 93.6 & 86.9 & 91.8 \\ \text { 8th " } & 139.2 & 110.9 & 79.7 \\ \text { 1Ith " } & 182.4 & 148.5 & 81.4\end{array}$

Series II.

$\begin{array}{ccc}\text { Average No. } & \text { Average } & \text { Calculated } \\ \text { Weight of } \\ \text { of Leaves. } & \text { Weight. } & \text { 100 Leaves. } \\ & m g . & m g . \\ 10 & 10.15 & 101.5 \\ 144^{\circ} .4 & 157.4 & 109.0 \\ 237.6 & 243.0 & 102.3 \\ 393.6 & 532.5 & 135.3\end{array}$


All the above figures indicate that, as in Lemna, not only is the rate of multiplication less in Detmer's solution without the presence of the growthpromoting organic substances, but there is also a diminution in size of the individual leaves as indicated by their weight. These facts were also very evident from the general appearance of the plants. The original plants placed in mineral nutrients only remained fairly healthy throughout the experiment, but the new leaves arising from them became successively smaller and more yellow in colour, indicating some interference with the metabolic activities of the plants. Those supplied with the organic substances remained perfectly healthy throughout the experiment, the new leaves arising becoming fully as large as, and in some cases larger than, the original ones. Pl. XVII, Fig. 3, shows a photograph of the whole set of dishes, taken in the last week of the experiment, and Pl. XVII, Fig. 4, shows one representative dish from each series on a larger scale taken at the same time. Both the difference in rate of multiplication of the leaves and the variation in their size are clearly shown in these two photographs.

\section{EXPERIMENT WITH AZOLLA FILICULOIDES.}

A set of ten dishes, divided into two series of five dishes each, was prepared in precisely the same way as for the Salvinia experiment. Into each of these dishes were counted out ten small sprigs of Azolla filiculoides, the sprigs being as nearly alike as possible. Since it was impossible to estimate the number of leaves on this plant, the number of visible growingpoints was counted, and the total number of growing-points introduced into each dish on the ten small portions of Azolla was eighty. Four similar sets were counted out at the same time, and their dry weight was estimated. The figures obtained were $16 \cdot 4,17 \cdot 0,16 \cdot 8$, and $16.6 \mathrm{mg}$. respectively, giving an average of $16.7 \mathrm{mg}$. as the dry weight of the original contents of each dish.

The culture solutions were changed twice weekly and the number of visible shoots counted once weekly. At the end of the fourth week the plants in Series II had filled their dishes, so the contents of all the dishes were halved, one half being retained and the dry weight of the other half estimated. This was repeated at the end of the fifth, sixth, eighth, and eleventh weeks.

The weekly figures for each dish are shown in the table below, the number of shoots being given in the upper portion of the table and the weights in the lower part. The figures given represent those for the com. plete set each week, and not for the fractions of the complete sets (onethirty-second part) which were actually in the dishes after the fourth week.

The contents of dishes No. $3,4,8$, and 10 were pressed and mounted as a permanent record, and photographs of these pressed plants are shown in Pl. XVII, Figs. 5 and 6. 


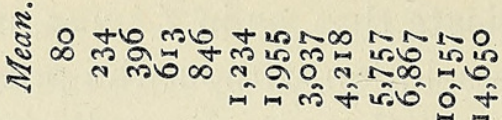

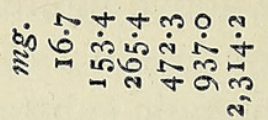

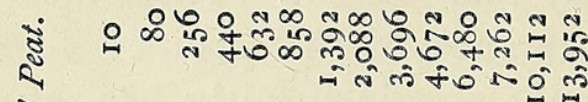

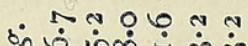

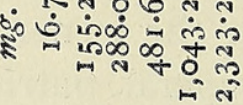

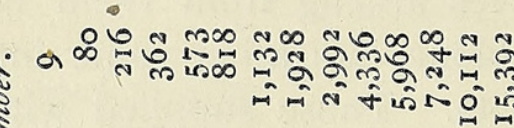

ஸें

$2 \frac{2}{2}$

范

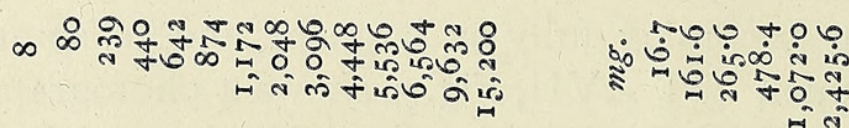

ถัँ

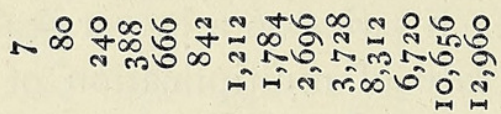

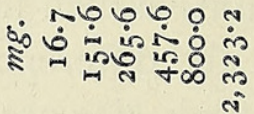

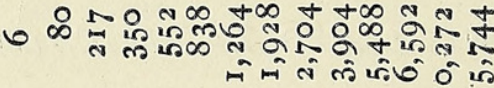

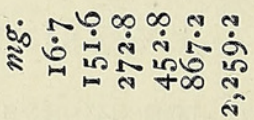

$\underset{5}{>}$

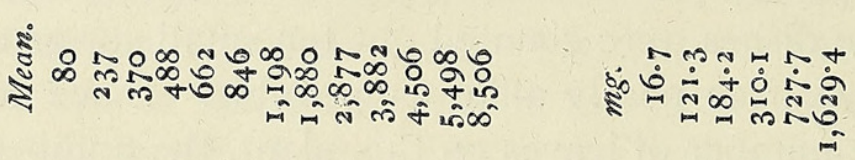

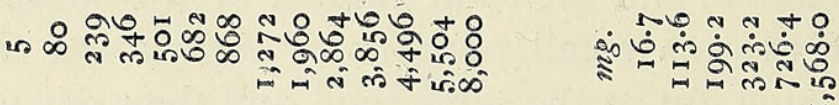

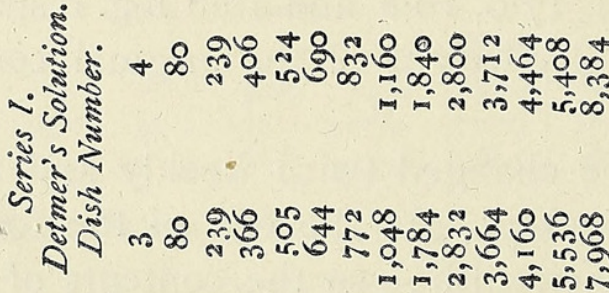

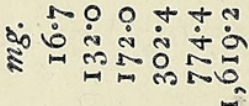

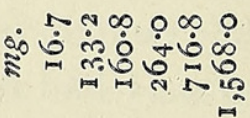

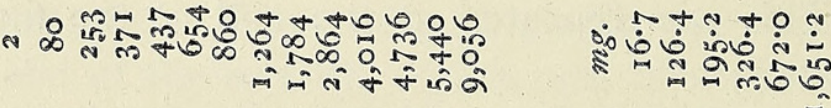

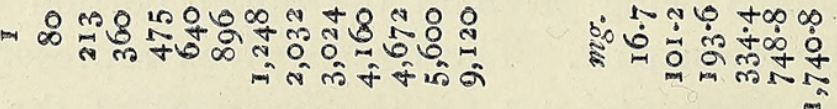

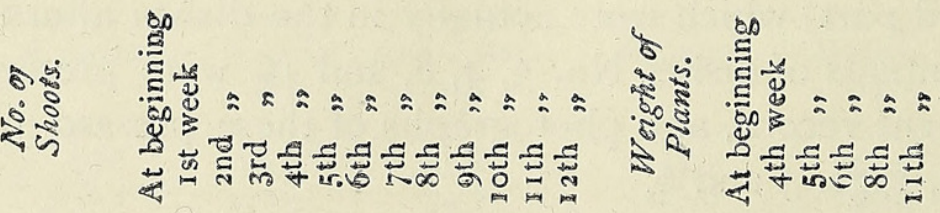


A comparison between the number of shoots in the two series is readily obtained by putting the average number in Series I at Ioo for each week, when the corresponding numbers for Series II are obtained for the twelve weeks-99, 107, I26, I28, I46, I63, I6 I, I47, I48, I52, I85, I 72. The fluctuation in these ratios from week to week is no doubt due to the unequal growth which had taken place during the varying weather conditions.

A corresponding comparison between the weights of the plants, putting the weight in both series at 100 for the beginning of the experiment, shows for Series II for the 4 th, 5 th, 6 th, 8 th, and IIth weeks respectively, the figures I $26, I_{44}, I_{52}, I_{2} 9$, and 142 .

It is evident from these figures that the plants of Azolla filiculoides respond to the presence of organic growth-promoting substances, although the response is not so marked as in the case of Salvinia and Lemna. Azolla plants, however, have long been known to be associated with an alga, Anabaena, which inhabits special cavities in the plants; and these cavities have also been shown by the writer ${ }^{1}$ to contain nitrogen-fixing organisms. The symbiotic nature of these plants is a factor which must be taken into consideration in any discussion of their nutrition, since it is quite probable that such an association may furnish the plant with a proportion of the necessary organic substances for its metabolism. Under these circumstances a smaller response to the addition of such substances than is the case in a normal plant would be expected; and it was the fact that these plants, in the mineral solution only, retained their healthy appearance to a much greater extent than in the case of the plants with which the previous trials were carried out.

The increase in weight of these Azolla plants grown in the solution containing organic matter was not quite commensurate with the increase in number of the shoots, but this is readily explained by the fact that the main shoots of the control series elongated rather more than did those in Series II, before giving rise to secondary shoots. Hence the average weight of the shoots in Series I is greater than that in Series II, although in the latter series the total weight and number of the shoots are markedly superior to those in Series I, indicating a better nutrition of the plants.

\section{EXPERIMENT WITH LIMNOBIUM STOLONIFERUM.}

On September 22 a number of small plants of Limnobium stoloniferum were obtained, sufficient to start two small series of four dishes each. Four of these dishes (Series I) contained 300 c.c. of Detmer's solution, and the other four (Series II) 300 c.c. of this solution containing also the extract of one gramme of bacterized peat in every 1,000 c.c. Into each dish six plants of Limnobium were put, care being taken to select all eight sets as

1 Bottomley, W. B.: Report Brit. Ass., 1910, pp. 786-7. 
equally as possible. Each dish contained three plants with two leaves each, one with three leaves, and two with four leaves, a total of six plants, bearing between them seventeen leaves, in each dish. The solutions were renewed twice weekly, and a weekly record was made of the number of plants and leaves. During the fourth week of the experiment the dishes were found to be practically full, so the contents of each dish were halved as exactly as possible on October I6. The dry weight of one half of each was estimated, and a calculation made of the total weight in the dish. The other half of each set was retained and the experiment continued until Nov. 4 , when growth was found to have practically ceased, for the experiment was carried out in an unheated greenhouse. The plants in each dish were counted, and the dry weight of the whole was determined. The results obtained are given below, and represent the figures corresponding to the complete sets at the respective dates.

TABLE VII.

\begin{tabular}{|c|c|c|c|c|c|c|c|c|c|}
\hline ries. & $\begin{array}{l}\text { Dish } \\
\text { No. }\end{array}$ & $\begin{array}{c}\text { Sep } \\
\text { Num } \\
\text { Plants. }\end{array}$ & $\begin{array}{l}22 . \\
\text { zber of } \\
\text { Leaves. }\end{array}$ & $\begin{array}{c}\text { Oct } \\
\text { Num } \\
\text { Plants. }\end{array}$ & $\begin{array}{l}16 . \\
\text { ber of } \\
\text { Leaves. }\end{array}$ & $\begin{array}{l}\text { Weight } \\
\text { of set. } \\
\text { gme. }\end{array}$ & $\begin{array}{c}\text { No } \\
\text { Num } \\
\text { Plants. }\end{array}$ & $\begin{array}{l}4 . \\
\text { Leaves. }\end{array}$ & $\begin{array}{l}\text { Weight } \\
\text { of set. } \\
\text { gm. }\end{array}$ \\
\hline titi & $\begin{array}{l}1 \\
2 \\
3 \\
4\end{array}$ & $\begin{array}{l}6 \\
6 \\
6 \\
6\end{array}$ & $\begin{array}{l}17 \\
17 \\
17 \\
17\end{array}$ & $\begin{array}{l}40 \\
38 \\
36 \\
36\end{array}$ & $\begin{array}{r}108 \\
100 \\
92 \\
100\end{array}$ & $\begin{array}{l}0.1612 \\
0.1496 \\
0.1752 \\
0.1728\end{array}$ & $\begin{array}{l}74 \\
66 \\
68 \\
56\end{array}$ & $\begin{array}{l}184 \\
192 \\
180 \\
174\end{array}$ & $\begin{array}{l}0.3^{2} 32 \\
0.3172 \\
0.3304 \\
0.2968\end{array}$ \\
\hline & Mean & 6 & 17 & $3 \% 5$ & 100 & 0.1647 & 66 & $182 . j$ & 0.3169 \\
\hline $\begin{array}{l}\text { I. } \\
\text { solutio } \\
\text { zed pea }\end{array}$ & $\begin{array}{l}5 . \\
6 \\
7 \\
8\end{array}$ & $\begin{array}{l}6 \\
6 \\
6 \\
6 \\
\end{array}$ & $\begin{array}{l}17 \\
17 \\
17 \\
17\end{array}$ & $\begin{array}{l}49 \\
48 \\
42 \\
44\end{array}$ & $\begin{array}{l}110 \\
108 \\
102 \\
104\end{array}$ & $\begin{array}{l}0.1896 \\
0.1672 \\
0.2092 \\
0.1780\end{array}$ & $\begin{array}{l}86 \\
76 \\
76 \\
78\end{array}$ & $\begin{array}{l}248 \\
222 \\
202 \\
202\end{array}$ & $\begin{array}{l}0.4840 \\
0.4560 \\
0.4388 \\
0.4556\end{array}$ \\
\hline & Mean & 6 & I7 & 45 & 106 & 860 & 79 & $218 \cdot 5$ & 0.4586 \\
\hline
\end{tabular}

Thus on October I6, after three weeks' growth, Series II, with organic matter, showed an increase of I 2 per cent. in the dry weight of the plants, and 6 per cent. in the number of leaves; but on Nov. 4, after a further three weeks' growth, the increase had amounted to 44.7 per cent. on the dry weight and 19 per cent. on the number of leaves. The plants in Series II appeared to be much more healthy than those in Series I, for the latter became very yellowish in appearance after the second week. The addition of the organic matter had a most marked effect on the health of the plants.

\section{CONCLUSION.}

The experiments recorded above demonstrate that the water plants employed all require a certain quantity of organic substance for their proper growth and development, and that they are unable to develop to their full extent in nutrient solutions containing minerals only. The maximum 
quantity of organic substance added in the above experiments never exceeded 184 parts per million, while the total concentration of mineral nutrients reached 5,500 parts per million. The effect of the organic matter could therefore not be attributed to its nutrient value, and it evidently functions as a growth-promoting substance, enabling the plants to make full use of the mineral substances supplied.

These plants would normally obtain such organic substance in the water of the ponds, \&c., in which they grow, and it is noteworthy that the slower the rate of multiplication of the particular plant employed, the longer is the period that elapses before it begins to appreciate the deficiency of the mineral nutrient solution, and to respond to the addition of organic substance. Such a plant as Lemna minor or major, which normally multiplies very rapidly, will exhaust its original supply of these necessary growth-promoting substances, and will therefore respond to their addition to the nutrient solution, much more quickly than will such a plant as Limnobium, which grows and multiplies at a comparatively slow rate.

The plants chosen in these experiments are such as would permit of a fairly accurate estimate of their growth by counting and weighing, but similar results have been obtained with other plants, such as Veronica beccabung $a$, and the plants used are sufficiently diverse in nature to warrant the conclusion that all water plants require organic substances for their proper growth and development. It also cannot be expected that water plants differ so fundamentally from all other plants as to stand alone in such a requirement, and the author has already shown ${ }^{1}$ that plants such as wheat seedlings, when the supply of organic material stored in their endosperm has been removed, respond very readily to the addition of such substances to the nutrient solution. An extension of these experiments with land plants, and particularly with cuttings, which have no seed to store up a quantity of organic substance, has been in progress for the last two years and will be reported in due course. The results of these experiments indicate that the same principle-the necessity for organic substance in small quantity-applies to ordinary land plants as well as to the water plants for which it has been established in the experiments recorded above.

\section{Summary.}

Lemna major, in common with Lemna minor, was found to be quite unable to maintain its normal health in water-culture solutions containing mineral nutrients only. Immature plants used at the beginning of the experiment failed to reach the adult size, while adult plants began to bud, but the young plants thus formed never matured.

1 Bottomley, W. B. : Annals of Botany, vol. xxviii, No. cxi, pp. 53I-40 ; Proc. Roy. Soc., B., vol. Ixxxviii, pp. $237-47$ (19I4). 
When organic substances were added to the culture solutions the plants, whether young or full-grown, grew quite normally and reproduced themselves rapidly, the offspring rapidly reaching the normal size.

The effective organic substances were found to be present in an autoclaved growth of Azotobacter chroococcum, crude nucleic acid derivatives from raw peat, and a water extract of bacterized peat.

Similar trials carried out with Salvinia natans showed that these plants also are unable to maintain themselves in health without the presence of organic growth-promoting substances. The plants originally placed in mineral nutrients only remained healthy, but all new leaves formed were successively smaller and more yellowish in appearance. The addition of organic matter to the solution resulted in a more rapid rate of growth, the new leaves formed rapidly reaching the full normal size, and remaining perfectly healthy in appearance.

Azolla filiculoides also responded to the presence of organic substances in the culture solution, although not to quite the same extent as in the case of the plants mentioned above. The control plants, in minerals only, remained healthy for a longer period than did the controls of these other plants, probably on account of the symbiotic habit of Azolla, which would of necessity result in the supply of a certain quantity of organic matter to the plants.

Plants of Limnobium stoloniferum were also experimented with, and it was found that the addition of organic substance materially improved the health and size, as indicated by weight, of the plants. In these, as in the preceding experiments, a marked effect of the organic addition was its influence on the colour of the plants, those in minerals only becoming yellowish after a time, while those supplied with organic substance retained their green colour.

In no case did the organic substance supplied exceed 184 parts per million, while the concentration of salts in the culture solution totalled 5,500 parts per million.

Throughout the experiment it was found that the more rapid the rate of multiplication of the plants, the quicker was the response to the addition of organic substance to the solution.

The plants, in nature, obtain their supplies from the water of the ponds and streams in which they grow, and the quantity of these organic substances present in their tissues at the beginning of the experiment will necessarily diminish more rapidly as their rate of multiplication is increased. The more rapidly-growing plants therefore respond more quickly to the addition of organic substances in their culture solutions. 


\section{EXPLANATION OF PLATE XVII.}

Illustrating Prof. Bottomley's paper on the Effect of Organic Matter on the Growth of various Water Plants in Culture Solution.

Fig. I. Lemna major. Contents of dish No. 2 (Table II), after four weeks' growth. Product of Io plants. About $\frac{1}{2}$ natural size.

Fig. 2. Lemna major. Contents of dish No. 6 (Table II), after four weeks' growth. Product of Io plants. About $\frac{1}{2}$ natural size.

Fig. 3. Salvinia natans. Ten dishes (Table III), photographed after eleven weeks' growth. Upper five dishes contained mineral nutrients only, lower five contained same mineral nutrients +184 parts per million of organic matter. Ten leaves originally placed in each dish. About $\frac{1}{\delta}$ natural size.

Fig. 4. Salvinia natans. One dish from each of the two groups above, upper dish containing mineral nutrients only, lower one containing mineral nutrients + organic matter. About $\frac{2}{5}$ natural size.

Fig. 5. Azolla filiculoides. Contents of dish No. 3 (Table VI), after twelve weeks' growth. One thirty-second part of product of 80 shoots. About $\frac{2}{5}$ natural size.

Fig. 6. Azolla filiculoides. Contents of dish No. Io (Table VI), after twelve weeks' growth One thirty-second part of product of 80 shoots. About $\frac{2}{5}$ natural size. 
Annals of Botany,

Lemna major.

Set 2 .

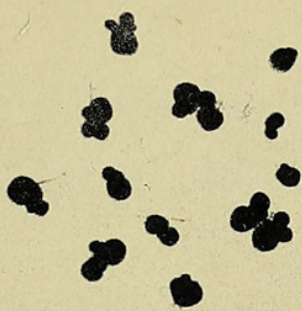

1.

In Minerals anly.

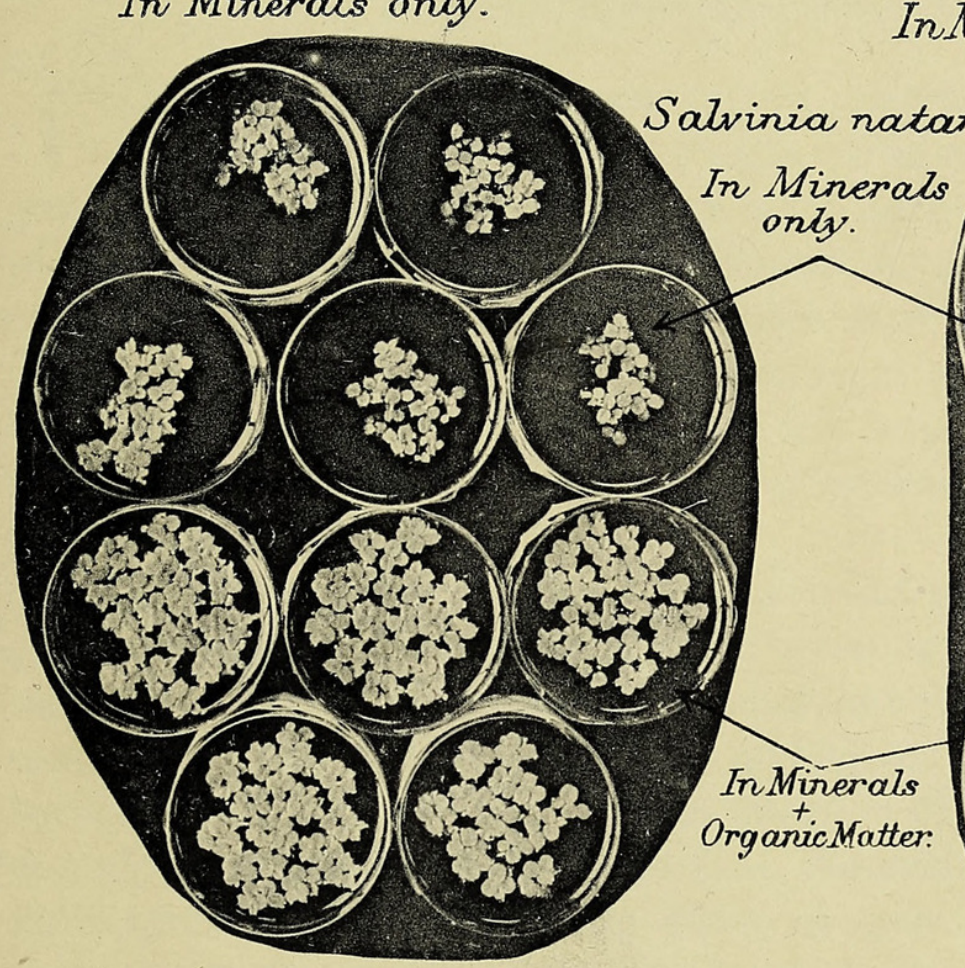

3.

Azolla fiticuloides.

Dish 3

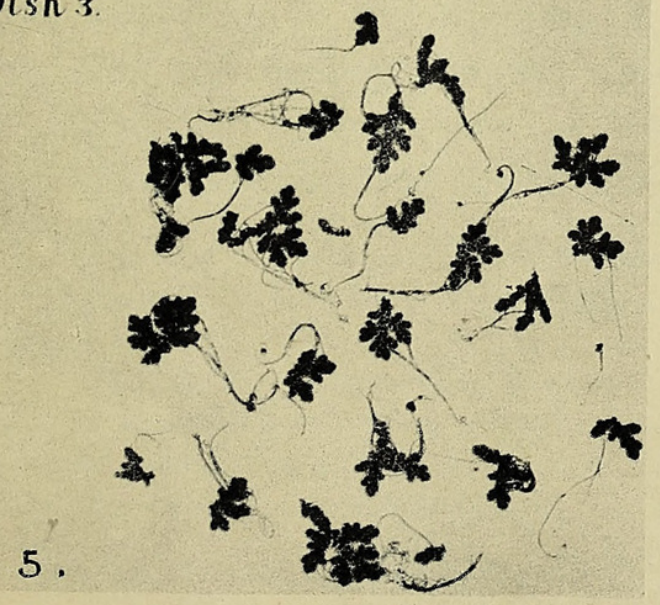

In Minerals only.

Dish ro.

6.
Vol.XXXIV, PL.XVII.

Set 6 .

\section{Lemna major.}

2.

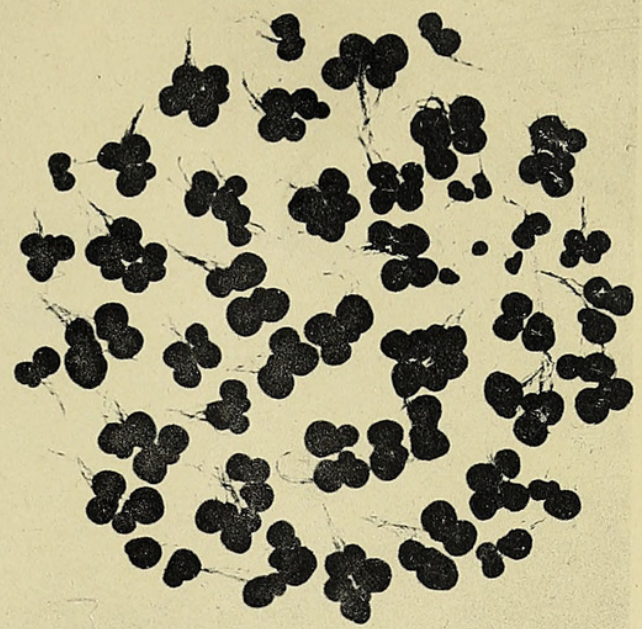

InMinerals + Organic Matter.

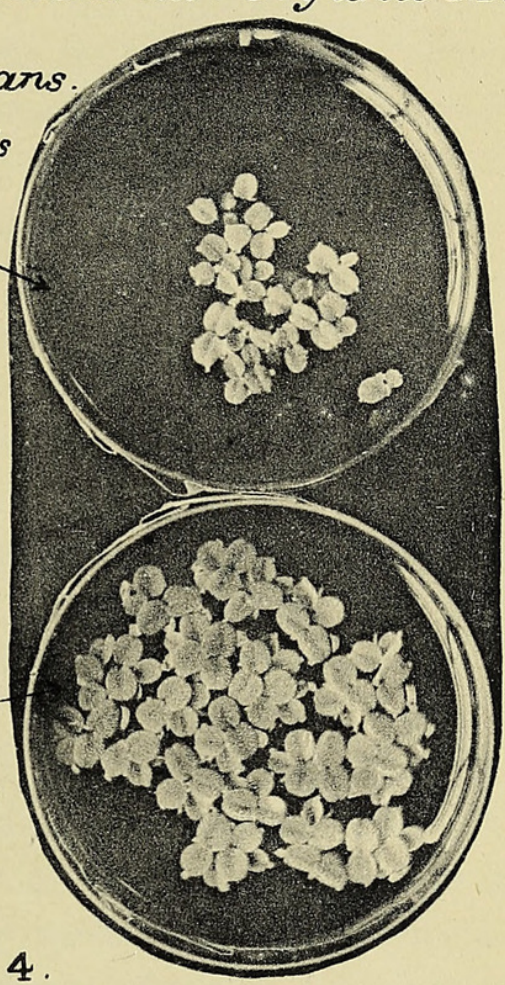

Azolla filiculoides.

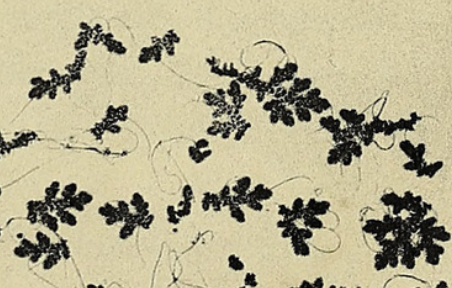

管 $+4+2+4$ + $4 *$ t 称数

In Minerals + Organuc Matter. 


\section{$2 \mathrm{BHL}$ Biodiversity Heritage Library}

Bottomley, W. B. 1920. "The effect of organic matter on the growth of various water plants in culture solution." Annals of botany 34, 353-365. https://doi.org/10.1093/aob/os-34.3.353.

View This Item Online: https://www.biodiversitylibrary.org/item/236972

DOI: https://doi.org/10.1093/aob/os-34.3.353

Permalink: https://www.biodiversitylibrary.org/partpdf/320293

\section{Holding Institution}

Smithsonian Libraries

\section{Sponsored by}

Biodiversity Heritage Library

\section{Copyright \& Reuse}

Copyright Status: Not in copyright. The BHL knows of no copyright restrictions on this item.

This document was created from content at the Biodiversity Heritage Library, the world's largest open access digital library for biodiversity literature and archives. Visit BHL at https://www.biodiversitylibrary.org. 